\title{
Trilobite faunal dynamics on the Devonian continental shelves of the Ardenne Massif and Boulonnais (France, Belgium)
}

\author{
Arnaud Bignon and Catherine Crônier \\ Acta Palaeontologica Polonica 60 (4), 2015: 949-962 doi:http://dx.doi.org/10.4202/app.00019.2013
}

During the Devonian the sedimentation on the continental shelves of Ardenne Massif and Boulonnais has changed from a mixed siliciclastic-carbonate ramp (Eifelian), through a carbonate barrier reef (Givetian) and then to a detritic influx with local mud-mounds (Frasnian). Here we analysed the faunistic dynamics of the trilobite associations through the changing environment. We used multivariate analyses (clustering and ordering) to discriminate the trilobite associations within 67 different samples. Three previously known communities and one new were recognised: the Eifelian Mixed association, the Givetian Dechenella association and the two Frasnian Bradocryphaeus and Scutellum-Goldius associations. These trilobite faunas present a progressive ecological specialisation. The Mixed association occurs both in the ramp or carbonated (local reef developed on the ramp) facies without any significant difference in its composition. The Dechenella fauna occurs preferentially close to barrier reefs, but can also survive during short periods of detrital input. The two Frasnian communities show a strong relationship with their environment. The Scutellum-Goldius association is only found in reef systems, whereas the Bradocryphaeus flourishes exclusively in lateral facies.

Key words: Trilobita, faunal succession, reefs, Devonian, France, Belgium, Ardenne Massif, Boulonnais.

Arnaud Bignon [arnaudbignon@yahoo.fr], Université Lille 1, UFR

Science de la Terre, UMR8217 GEOSYSTEMES, 59655, Villeneuve d'Ascq Cedex, France; and Department of Geology and Geophysics, Yale University, New Haven, CT 06511, USA; Catherine Crônier [catherine.cronier@univ-lille1.fr], Université Lille 1, UFR Science de la Terre, UMR 8217 GEOSYSTEMES, 59655, Villeneuve d'Ascq Cedex, France 
This is an open-access article distributed under the terms of the Creative Commons

Attribution License (for details please see creativecommons.org), which permits unrestricted use, distribution, and reproduction in any medium, provided the original author and source are credited.

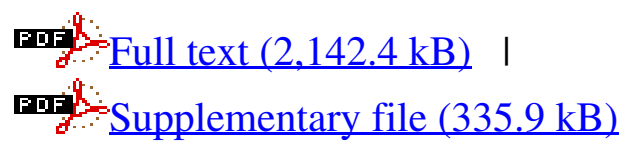

